\title{
Quality of eggs sold in different commercial establishments and the study of the conditions of storage
}

\author{
Anielli Souza PEREIRA ${ }^{1}$, Taisa Tavares dos SANTOS ${ }^{1}$; Ana Flávia Santos COELHO ${ }^{1 \star}$
}

\begin{abstract}
The objective of this study was to investigate the influence of storage conditions on the physicochemical (mass, albumen height, $\mathrm{pH}$, and Haugh unit) and microbiological (Salmonella spp., determination of the Total and Thermotolerant Coliforms, and Counting of the Mesophilic Aerobic Bacteria) quality of eggs. In the first experiment, a questionnaire was applied, and 33 samples of eggs were collected for the Salmonella spp analysis. In the second experiment, the eggs were collected from supermarkets, open markets, and distributors for physicochemical analysis. In the third experiment, 175 eggs were collected from the distributor, packaged in cardboard boxes lined with plastic wrapping, stored at $5{ }^{\circ} \mathrm{C}$ and $28^{\circ} \mathrm{C}$, and the physicochemical and microbiological analyses were performed at 7, 14, and 21 days of storage. In the first experiment, $100 \%$ of the samples analyzed showed no Salmonella spp. In the second experiment, it was found that the values of physicochemical parameters were in agreement with those in the literature. However, in the third experiment, the physicochemical parameter results showed statistical difference during storage and temperatures studied. Salmonella spp. were found in the samples stored at room temperature and in the refrigerated samples. Mesophilic microorganisms with values ranging from $<10 \mathrm{CFU} \mathrm{g}^{-1}$ (estimated) to $8.0 \times 10^{3} \mathrm{CFU} \mathrm{g}^{-1}$ and coliforms to $4 \mathrm{NMP.g}^{-1}$ were also found, but the presence of E. coli was not confirmed.
\end{abstract}

Keywords: microbiological quality; egg; Samonella spp.; haugh unit.

\section{Introduction}

The commercialized egg is the product of an efficient biological transformation done by the egg-laying hen, in which food resources of lower biological value are transformed into a high nutritional quality product for human consumption (Souza-Soares \& Siewerdt, 2005). The egg main function is reproduction but, it is highly consumed by the Brazilian population due to its affordable price, and it is also a part of a consumption pattern because it can be consumed in its natural form or as an ingredient in some foodstuffs such as cakes, meringues, and confectionery products and derivatives (Aragon-Alegro et al., 2005). Its use in these food preparations is due to its capacity to form a foamy texture due to the air entrapment in a prosthetic net, which is an important property to obtain a foamy emulsion and mousse (Alleoni \& Antunes, 2001).

The egg is one of the most complete foods that exist. It is composed of proteins, carbohydrates, lipids, vitamins, minerals, and essential fatty acids; each component has a specific function to meet human nutrition requirements (Costa et al., 2006). It should be noted that these components can change according to the chicken diet, and that its age influence only the size of the egg and not its nutritional composition (Souza-Soares \& Siewerdt, 2005).

Due to its nutritional and technological potential value to be optimized by man, the egg needs to be preserved during its marketing period since it may take weeks from the time of laying to its acquisition and preparation. The longer this time period, the worse the internal quality of the eggs since after there are laid, they lose quality continuously (Leandro et al., 2005).

The reduction in the internal quality of eggs is mainly associated to the loss of water and carbon dioxide during the storage period, and it is proportional to the increase in the temperature of the environment. As for the assessment of the albumen height, when the egg is broken out onto a smooth surface, its quality can be determined since as it ages the proportion of albumin increases at the expense of the liquid density. The loss of carbon dioxide during storage results in a change of the egg flavor as a consequence of the increase in alkalinity, besides the numerous chemical reactions involving the carbonic acid in the egg inside. Thus, good quality fresh eggs have a neutral $\mathrm{pH}$ and the egg white will be limpid, clear, consistent, dense and thick, with a small fluid portion (Leandro et al., 2005).

Laganá et al. (2012) showed that the values obtained for specific gravity, percentage of albumen, and yolk were significantly higher at the beginning of shelf life, in comparison to the later periods of storage. The percentage of albumen and yolk characteristics related to internal egg quality worsened linearly during the storage period. The yolk percentage was inversely proportional to the albumen percentage.

Most eggs have little or no contamination at the time of laying; this usually occurs after oviposition. However, contamination may also occur transovarially, in which the infected chicken transmits contamination to the eggs. Among the major means of contamination is the contact of the eggs with 
the faeces of chickens at the time of laying and the penetration of microorganisms through microscopic cracks or the pores of the shell after washing (Aragon-Alegro et al., 2005).

In addition to the preservation of egg's internal characteristics, microbiological contamination is also a feature that should be controlled in order to obtain eggs with quality for human consumption. Among the microorganisms found in eggs, Salmonella spp. is the only pathogen microorganism for humans and its optimum growth temperature varies from 43.2 to $46.2^{\circ} \mathrm{C}$ (maximum value) and from 5.3 to $6.8^{\circ} \mathrm{C}$ (minimum value), the greatest risk is between 15 and $40^{\circ} \mathrm{C}$.

It is important to note that Salmonella spp. cannot change the odor or the appearance of the egg, which makes them pass in the contamination inspection (International Commission on Microbiological Specifications for Foods, 1980).

The detection of the presence of other microorganisms is also important because even if pathogens are absent, there were no changes in the food organoleptic conditions, a large number of microorganisms indicate that food is unhealthy. Escherichia coli can be used as an indicator of fecal contamination, which is an indicative of inadequate cleaning procedures and/or storage. Another important group of organisms to be analyzed is that of the Mesophilic Aerobic Bacteria, which may cause deterioration or reduction in the shelf life of these foods; besides the fact that all pathogenic bacteria are in this group, and it is also an indicative of failure in the cleaning process (Franco \& Landgraf, 2002).

Therefore, storage plays a major role in the conservation of eggs, since it is during this period the physical, chemical and microbial changes occur (Souza-Soares \& Siewerdt, 2005).

Time and temperature storage are fundamental factors for efficient conservation. The disinfection is usually done by washing the eggs with a detergent solution followed by sanitizing it with a chlorine solution and the spraying of mineral oil; cooling the egg soon after laying is recommended as a measure to reduce contamination and microbial growth, and, according to the literature, the storage temperature should be around $15{ }^{\circ} \mathrm{C}$, preferably below $10^{\circ} \mathrm{C}$ (International Commission on Microbiological Specifications for Foods, 1980).

In the United States, the Food and Drug Administration (FDA) recommends that eggs are stored under refrigeration of at least $5{ }^{\circ} \mathrm{C}$ (Rodrigues \& Salay, 2001). In Brazil, the Agência Nacional de Vigilância Sanitária (ANVISA) establishes sanitaryhygienic measures that include safe handling, storage and food preparation, besides permitting refrigerated conservation made by fan air circulation at a temperature greater than - 1 ${ }^{\circ} \mathrm{C}$ (Brasil, 1952).

In spite of these existing recommendations, most establishments do not adhere to them and thus, the food does not reflect the quality and shelf life as it should have. Therefore, there is a need for studies to verify how the conditions of storage interfere with the quality of the eggs, and the results obtained should be presented to the business owners.

Relevant Studies to verifying the quality of the eggs sold without pre-conditions and also the pointing out of the storage conditions for this food as a way to slow down its deterioration and prevent the occurrence of food poisoning. Thus, the aim of this study was to study the influence of storage conditions on the physical, chemical, and microbiological quality of eggs sold in different shops, as well as to provide data to point out the need for an update of the legislation for the storage of the eggs under refrigeration.

\section{Materials and methods}

In the first experiment, a questionnaire was prepared with a check list to verify: the origin of raw materials, the transportation of the egg sold in shops; cleaning the egg shells; the types of packaging used for the packaging of eggs; the storage conditions (temperature and humidity). The questionnaire was administered at the collection time made in supermarkets, open market and distributors, each sample consisted of 12 fresh eggs. Next, 33 samples were prepared, each with four eggs for Salmonella spp counts in the eggshell and inside the shell or in the egg contents.

The eggshell surface was swabbed for samples (4 samples). The swabs were placed in test tubes containing $10 \mathrm{ml}$ of Lactose Broth dilution and incubated at $35^{\circ} \mathrm{C}$ for $18 / 24$ hours for preenrichment. For the analysis of the inside of the contents inside the eggshell, the same eggs were used. They were washed with water and detergent, drained to remove excess water, dipped in $70 \%$ alcohol for 10 minutes and then flamed. After this, the shells were cracked and the contents were poured into a sterile vial, and homogenized for 1 to 2 minutes. The sample was withdraw $(10 \mathrm{ml})$ and discarded into a flask containing $90 \mathrm{ml}$ of Lactose Broth dilution to $10^{-1}$ and were incubated (with slightly loose caps) at $35^{\circ} \mathrm{C}$ for $18 / 24$ hours for pre-enrichment. Next, the two dilutions (eggshell and contents inside the shell) followed the steps of enrichment and plating described by Silva et al. (1997).

In the second experiment, the eggs were purchased from supermarkets, open markets, and distributors to determine the physicochemical analysis (weight, thick egg white height, $\mathrm{pH}$, and Haugh unit). For each category, there were three repetitions, each consisting of 4 eggs.

For the determination of the weight, a semi-analytical balance (Bioprecisa/BS3000A) was used. Then they were broken onto a flat glass surface and the albumen height was measured with a caliper (Mitutoyo). The yolk and the egg white were mixed, and the $\mathrm{pH}$ was determined using a $\mathrm{pH}$ meter (Marte/ MB-10). The Haugh Unit was calculated using the following Equation 1:

$\mathrm{UH}=100 \log \left[\mathrm{H}-\left(1,7 \mathrm{M}^{0,37}\right)+7,6\right]$

where: $U H$ - Haugh unit; $H$ - albumen height (mm); $M$ - egg weight $(\mathrm{g})$.

A completely randomized design was used, and the results were analyzed by comparison using the Tukey test $(\mathrm{P}<0.05)$ and the SISVAR (Ferreira, 2002) software.

In the third experiment, 175 eggs were purchased and packaged in cardboard boxes lined with plastic wrapping. 
A total of 24 eggs Were analyzed on the collection day; 12 were used for physicochemical analysis and 12 for microbiological analysis The remaining eggs were spilt in half; one half was stored in the refrigerator at $5^{\circ} \mathrm{C}$, and the other half was stored in in a $\mathrm{B} \mathrm{O}$ D oven at a temperature of $28^{\circ} \mathrm{C}$ (common storage temperature at the business establishments) The eggs were analyzed after periods of 7,14 , and 21 days of storage.

The physicochemical analyses were the same as those used in the second experiment. The following microbiological analyses were performed: Salmonella spp., determination of the Total Coliforms and Thermotolerant coliforms, and Counting of the Mesophilic Aerobic Bacteria.

The same method used in the first experiment was used for Salmonella spp counts in the eggshell and inside the shell.

The determination of microorganisms of the group Coliform and Counts of Mesophilic Aerobic Bacteria was performed in the eggshell according to the method described by Silva et al. (1997), in which the eggshell surface of 4 eggs was swabbed for samples, and the swabs were placed in test tubes containing $10 \mathrm{ml}$ of saline peptone for dilution; dilutions of $10^{-1}$, $10^{-2}$, and $10^{-3}$ were made.

The typical colonies of Salmonella spp. were tested with Gram Test and the biochemical tests TSI, LIA, Simmons Citrate, Lysine Decarboxylase, Phenylalanine Deaminase, Methyl Red, Vogues-Proskauer, Indol, and Motility. Colonies typical of $E$. coli were also tested with Gram Test Stick and Indol, Methyl Red, Vogues-Proskauer, and Simmons Citrate, according to the method described by Silva et al. (1997).

\section{Results and discussion}

The results of the questionnaires revealed that $54.5 \%$ of the eggs sold in Palmas/TO are transported in trucks and 45.5\% in open small trucks without any storage control of humidity and temperature. Most eggs belonged to the White Group; where there was no classification of the A, B, or C classes, but in terms of Type, the majority was Big or Medium: The common packaging used was cardboard boxes type (81.8\%), and cleanliness was rated as Good for $54.5 \%$ and as Average for $36.4 \%$ of all eggs analyzed.

The results revealed the profile of eggs sold in small and medium-sized supermarkets and open markets in the city of Palmas/TO. The transport conditions and the cleanness of the eggshells may have influenced the quality of the eggs evaluated.

In the first experiment, 33 samples were analyzed, totaling 132 eggs. The results for the Salmonella spp. assay showed the absence of microorganisms in all samples analyzed. Despite the occurrence of numerous contamination cases in eggs or foods prepared with eggs, the samples met the standards required by the legislation, which establishes the absence of any kind of Salmonella spp. for any type of food (Brasil, 2001).

Taham \& Oliveira (2011), in a study on Salmonella spp., also observed the absence of microorganisms in $67 \%$ of the samples of eggs sold in Brasília (Federal District). These data corroborate those obtained by Rego et al. (2012), who investigated commercial pasteurized eggs (fresh) and did not detect the presence of Salmonella spp. in any of the 48 samples either.

Aragon-Alegro et al. (2005) analyzed the microbiological quality of whole eggs, washed and unwashed with chlorine solution $(200 \mathrm{ppm})$ in 3 different stages of the production line of the pasteurized eggs: breaking, storage (tank), and the post-pasteurization. It was observed that in the washing step there was no significant statistical difference in the relation to contamination by Salmonella spp., but the most important observation was that these pathogens were eliminated after the pasteurization process.

Table 1 shows the average temperatures in each collection site; temperature and the humidity were not controlled by the establishments evaluated were not controlled by any of the establishments that were visited; the storage temperature values obtained were not within recommended range in the literature (International Commission on Microbiological Specifications for Foods, 1980).

Eggshell cleaning is one of the most important factors to prevent microbiological contamination since the major contamination of the eggs is through the feces. However, even after being washed and sanitized, the eggs may be contaminated from the outside, which makes packaging, transporting, and storage critical factors for the quality of the final product.

Table 2 shows the average results of the physicochemical analyses of the second experiment. The average weight values ranged from 48.98 to $58.02 \mathrm{~g}$; however, no statistical difference was found between them. Hermiz et al. (2012) found an average weight of 58, $44 \mathrm{~g}$ for fresh eggs, which are similar to the values found in this study. However, Carvalho et al. (2007) analyzed eggs of different strains and different laying ages and found weight values higher than those found in the present study; it was verified that the higher the age, the higher the weight found.

Table 1. Average storage temperatures of the eggs at the time of data collection.

\begin{tabular}{cc}
\hline Data collection places & Average temperature $\left({ }^{\circ} \mathrm{C}\right)$ \\
\hline Medium sized supermarket & 28.3 \\
Small sized Supermarket & 28.8 \\
Open Market & 28.6 \\
\hline
\end{tabular}

Table 2. Values of weight, albumen height, $\mathrm{pH}$, and Haugh unit of the eggs collected in different commercial establishments.

\begin{tabular}{ccccc}
\hline Establishments & $\begin{array}{c}\text { Weight } \\
(\mathrm{g})\end{array}$ & $\begin{array}{c}\text { Height } \\
(\mathrm{mm})\end{array}$ & $\mathrm{pH}$ & $\begin{array}{c}\text { Haugh } \\
\text { unit }\end{array}$ \\
\hline Small sized Supermarkets & $54.68 \mathrm{a}$ & $3.34 \mathrm{a}$ & $8.05 \mathrm{a}$ & $52.79 \mathrm{a}$ \\
Medium sized Supermarkets & $58.02 \mathrm{a}$ & $4.23 \mathrm{a}$ & $7.77 \mathrm{a}$ & $61.42 \mathrm{a}$ \\
Open Markets & $54.40 \mathrm{a}$ & $4.62 \mathrm{a}$ & $7.65 \mathrm{a}$ & $67.16 \mathrm{a}$ \\
Distributors & $48.98 \mathrm{a}$ & $3.98 \mathrm{a}$ & $8.16 \mathrm{a}$ & $63.30 \mathrm{a}$ \\
\hline
\end{tabular}

Values followed by the same lowercase letter in the column are not statistically different from each other (Tukey test, $5 \%$ of probability). 
The average values of albumen height ranged from 3.34 to $4.62 \mathrm{~mm}$. Leandro et al. (2005) found very close to those of eggs sold in supermarkets, popular markets, and open markets, although finding an average of $10.17 \mathrm{~mm}$ for eggs collected from aviaries.

The $\mathrm{pH}$ of the eggs analyzed was very close to neutral $\mathrm{pH}$, which can facilitate microbial growth.

Giampietro-Ganeco et al. (2012) found that storage at lower temperatures (cooling) is more efficient in maintaining the quality characteristics of the eggs regardless of the days of storage because place and time of storage of the eggs did not influence the yolk $\mathrm{pH}$, indicating that regardless of the place of cooling (inside the refrigerator or on its door) or the days of storage, the $\mathrm{pH}$ of the yolk did not change.

The average values of Haugh unit ranged from 52.79 to 67.16 , but they are not statistically different from each other. It is also an indicative of the internal quality of the egg since the weight and albumen height are directly proportional. The values found agree with those reported by Leandro et al. (2005) and Garcia et al. (2010), who observed that the percentage of albumen is reduced only when the eggs were stored in an environment with no temperature and humidity control.

Table 3 presents the average values of weight, albumen height, $\mathrm{pH}$, and Haugh unit of the eggs analyzed in the third experiment.

The average values found for the eggs analyzed did not differ statistically during storage at the temperatures of $5{ }^{\circ} \mathrm{C}$ and 28 ${ }^{\circ} \mathrm{C}$, but they were lower than the values found in the literature; a fact which can be explained by the type of eggs analyzed, Type 4 (small). Alleoni \& Antunes (2001) found that the weight of the eggs at room temperature ranged from $56.40 \mathrm{~g}$ to $67.56 \mathrm{~g}$. Leandro et al. (2005) analyzed large size eggs sold in different types of establishments in the city of Goiânia/GO and found an average weight of $60.92 \mathrm{~g}$.

Table 3. Average results of weight, albumen height, $\mathrm{pH}$, and Haugh unit according to days and storage temperature.

\begin{tabular}{|c|c|c|c|c|}
\hline \multirow{2}{*}{$\begin{array}{c}\text { Storage } \\
\text { Temperature }\end{array}$} & \multicolumn{4}{|c|}{ Days } \\
\hline & 0 & 7 & 14 & 21 \\
\hline & \multicolumn{4}{|c|}{ Weight (g) } \\
\hline $5^{\circ} \mathrm{C}$ & $45.96 \mathrm{aA}$ & $48.06 \mathrm{aA}$ & $46.88 \mathrm{aA}$ & $45.59 \mathrm{aA}$ \\
\hline \multirow[t]{2}{*}{$28^{\circ} \mathrm{C}$} & $45.96 \mathrm{aA}$ & $46.53 \mathrm{aA}$ & $46.54 \mathrm{aA}$ & $46.19 \mathrm{aA}$ \\
\hline & \multicolumn{4}{|c|}{ Albumen Height (mm) } \\
\hline $5^{\circ} \mathrm{C}$ & $4.11 \mathrm{aA}$ & $5.46 \mathrm{bA}$ & $4.78 \mathrm{bA}$ & $4.97 \mathrm{bA}$ \\
\hline \multirow[t]{2}{*}{$28^{\circ} \mathrm{C}$} & $4.11 \mathrm{aA}$ & $3.64 \mathrm{aAB}$ & $3.30 \mathrm{aAB}$ & $2.41 \mathrm{aB}$ \\
\hline & \multicolumn{4}{|c|}{$\mathrm{pH}$} \\
\hline $5^{\circ} \mathrm{C}$ & $7.98 \mathrm{aB}$ & $7.68 \mathrm{aA}$ & $7.43 \mathrm{aA}$ & $7.43 \mathrm{aA}$ \\
\hline \multirow[t]{2}{*}{$28^{\circ} \mathrm{C}$} & $7.98 \mathrm{aA}$ & $7.78 \mathrm{aA}$ & $7.96 \mathrm{bA}$ & $8.01 \mathrm{bA}$ \\
\hline & \multicolumn{4}{|c|}{ Haugh Unit } \\
\hline $5^{\circ} \mathrm{C}$ & $66.21 \mathrm{aA}$ & $76.91 \mathrm{bA}$ & $71.55 \mathrm{bA}$ & $74.44 \mathrm{bA}$ \\
\hline $28^{\circ} \mathrm{C}$ & $66.21 \mathrm{aA}$ & $61.58 \mathrm{aAB}$ & $57.40 \mathrm{aAB}$ & $46.98 \mathrm{aB}$ \\
\hline
\end{tabular}

Means followed by the same lowercase letter in the columns and uppercase letter in the rows do not differ statistically from one another by the Tukey test at $5 \%$ probability, considering the same physicochemical parameter.
Freitas et al. (2011) reported a weight loss in the eggs that were stored without any temperature control. According to these authors, the eggs' weight loss was due to the reduction of water in the albumen since the ratio decreased as a function of the storage time, which was significantly greater in the eggs that were kept at room temperature. In their study, it was found that when eggs were kept at a refrigerated at temperature of $10{ }^{\circ} \mathrm{C}$, there was less weight loss for 21 days of storage.

The weight loss of the eggs increases linearly with increased storage time. However, these losses are greater when the eggs are stored without control of humidity and temperature. Barbosa et al. (2008) demonstrated that eggs subjected to a controlled environment had an average loss of $3.63 \%$ of the initial weight, while the eggs stored in an uncontrolled environment had an average loss of 9.20\%. However, Keener et al. (2006) found that the egg average weight of $62 \mathrm{~g}$ was kept without any influence of storage time, and there was no significant difference between the weight of the eggs and the temperatures analyzed.

As for the albumen height, a significant difference was obtained in the eggs that were stored at room temperature from day 0 to 21 days and the storage temperatures of 7,14 , and 21 days, which proves that the internal quality of the egg decreases with time and that the cooling temperature also influences egg internal quality. Furthermore, the results were lower than those found in the literature. This can be justified by the time between laying and delivery to the distributor, which was of 6 days, since the aviaries were located far from the aviaries establishments evaluated.

The average values found by Alleoni \& Antunes (2001) for the albumen height ranged from 2.00 to $9.70 \mathrm{~mm}$.

The $\mathrm{pH}$ of the eggs analyzed differed significantly between day 0 and the remaining days for the refrigerated temperature and the storage temperatures between days 14 and, 21 this is due to the fact that the $\mathrm{pH}$ of the egg white increases with increased storage period of the egg. In a study by Rego et al. (2012), it was found that there was a reduction in the $\mathrm{pH}$ value of commercial pasteurized eggs from the 14th day of storage.

According Alleoni \& Antunes (2001), the pH of the egg white of a newly laid egg usually ranges from 7.6 to 7.9. Most microorganisms grow at this $\mathrm{pH}$ although this value is above the ideal. However, the $\mathrm{pH}$ of the egg white increases with increased storage period of the egg, and it can reach up to 9.5, which usually has an inhibitory effect on bacteria growth. The average values found in the present study are consistent with those found by these authors.

Haugh Unit as a measure of the internal quality of the egg differed significantly between day 0 and day 21 of storage at room temperature. Comparing the temperature of all days of of the , it was observed that there was a significant difference, except for day zero, and such difference increased over the time of storage. The results found by Garcia et al. (2010) confirmed an interaction between the preservation system and storage period for the Haugh Unit values obtained for the eggs, which presented a quadratic reduction when they were stored at room temperature. However, this did not happen at cool storage. 
Barbosa et al. (2008) observed that as storage time increases, there is a decrease in the Haugh Unit and the specific gravity; in addition, this also causes weight loss in a linear percentage caused by the loss of water from the albumen because its proportion reduced with storage time.

According to Giampietro-Ganeco et al. (2012), in a study in which the eggs were stored in a refrigerator, they found that the best values of the Haugh unit were obtained, i.e, the bestquality of eggs, was obtained up to 28 days of storage. And that the storage of eggs inside the refrigerator proved more efficient ensuring better quality.

As for the presence of Salmonella spp., $10.35 \%$ of the suspected colonies were confirmed, $5.26 \%$ on day 0 at a room temperature and $5.26 \%$ after 14 days under refrigerated temperature. It is important to note that the $\mathrm{pH}$ values found on these days of storage are conducive for the growth of Salmonella spp. The results are similar to those reported by Oliveira \& Silva (2000), who analyzed 124 commercial chicken eggs collected from retail stores in Campinas/SP and found Salmonella in 12 (9.6\%) and 4 (3.2\%) samples of eggshell and yolk, respectively.

The Mesophilic Aerobic Bacteria values ranged from $<10 \mathrm{CFU} \mathrm{g}{ }^{-1}$ (est) to $8.0 \times 10^{3} \mathrm{CFU} \mathrm{g}^{-1}$, and were the highest concentrations of microorganisms found in eggs subjected to storage at room temperature of 14 days. Naves et al. (2007) analyzed the microbiological quality of eggshell powder in Goiânia/GO and observed a mesophilic aerobic count of $1.8 \mathrm{x}$ $10^{2} \mathrm{CFU} \mathrm{g}^{-1}$ and $3.0 \times 10^{3} \mathrm{CFU} \mathrm{g}^{-1}$.

The coliform group was found in one of the samples after 14 days storage under refrigerated temperature. The total thermotolerant coliforms count were 4 NMP.g-1 ${ }^{-1}$ but the presence of E. coli was not confirmed. Rego et al. (2012), in a study on commercial pasteurized eggs, found a total coliforms ranging from $<0.3-\mathrm{NMP.g}{ }^{-1}$ to $110 \mathrm{NMP.g}{ }^{-1}$. However, there were no coliforms during the storage period at $45^{\circ} \mathrm{C}$ in commercial pasteurized whole eggs.

Storage conditions play a key role in preserving the quality of eggs both internally and microbiologically. However, the age of the eggs is the most important factor for the loss of quality because the longer the time after laying, the greater the reactions that take place inside the eggs and the greater the likelihood of contamination, and therefore, the business ownwers had no control of it. Therefore, refrigerated and adequate storage facility as well as expiration date monitoring are very important factors to assure egg quality.

\section{Conclusions}

The questionnaire applied in the first experiment revealed that $100 \%$ the eggs sold en Palmas/TO are transported in trucks without any storage control of humidity and temperature. Most eggs belong to the white group, are large or medium sized, and were packaged in cardboard boxes. Samonella spp was not detected in the samples although cleaning was classified as good in only $54.5 \%$ of the samples. It was observed that temperature and humidity were not monitored by any of the establishments visited.
The physicochemical analysis performed in the second experiment showed no statistical difference between the weight values, albumen height, $\mathrm{pH}$, and Haugh unit of the eggs collected from different commercial establishments and that these values are in agreement those in the literature.

The results of the third experiment showed that the internal quality of the egg decreased over time during storage, and that the refrigerated temperature also influences its quality. Salmonella spp. was found in eggs stored at $5{ }^{\circ} \mathrm{C}$ e $28^{\circ} \mathrm{C}$. The Mesophilic Aerobic Bacteria values ranged from $<10 \mathrm{CFU} \mathrm{g}^{-1}$ (est) to $8.0 \times 10^{3} \mathrm{CFU} \mathrm{g}^{-1}$ and were the highest concentration of microorganisms found in the eggs stored at $28^{\circ} \mathrm{C}$ for 14 days. The result of the count of total of thermotolerant coliforms was 4 NMP.g ${ }^{-1}$, but the presence of $E$. coli was not confirmed.

\section{References}

Alleoni, A. C. S., \& Antunes, A. J. (2001). Unidade Haugh como medida da qualidade de ovos de galinha armazenados sob refrigeração. Scientia Agricola, 58(4), 681-685. http://dx.doi.org/10.1590/S010390162001000400005

Aragon-Alegro, L. C., Souza, K. L. O., Costa Sobrinho, P. S., Landgraf, M., \& Destro, M. T. (2005). Avaliação da qualidade microbiológica de ovo integral pasteurizado produzido com e sem a etapa de lavagem no processamento. Ciência e Tecnologia de Alimentos, 25(3), 618-622. http://dx.doi.org/10.1590/S0101-20612005000300036

Barbosa, N. A. A., Sakomura, N. K., Mendonça, M. O., Freitas, R., \& Fernandes, J. B. K. (2008). Qualidade de ovos comerciais provenientes de poedeiras comerciais armazenados sob diferentes tempos e condições de ambientes. Ars Veterinary, 24(2), 127-133.

Brasil. (2001). Dispõe sobre padrões microbiológicos em alimentos (Regulamento técnico $\mathrm{n}^{\mathrm{o}} 12$, de 02 de janeiro de 2001). Diário Oficial da República Federativa do Brasil.

Brasil. Ministério da Agricultura, Pecuária e Abastecimento - Mapa. (1952). Regulamento de inspeção industrial e sanitária de produtos de origem animal. Inspeção industrial e sanitária dos ovos e derivados (Decreto nº 30.691, de 29 de março de 1952). Diário Oficial da República Federativa do Brasil.

Carvalho, F. B., Stringhini, J. H., Jardim Filho, R. M., Leandro, N. S. M., Café, M. B., \& Deus, H. A. S. B. (2007). Qualidade interna e da casca para ovos de poedeiras comerciais de diferentes linhagens e idades. Ciência Animal Brasileira, 8(1), 25-29.

Costa, F. G. P., Batista, A. S. M., Beltrao Filho E. M., Dal Monte, H. L. B., Jordao Filho, J., \& Pereira, V. O. (2006). Enriquecimento de ovos. Higiene Alimentar, 21(140), 16.

Ferreira, D. F. (2002). Manual do sistema Sisvar para análises estatísticas. Lavras: Departamento de Ciência Exatas/UFLA.

Franco, G. M., \& Landgraf, M. (2002). Microbiologia de Alimentos. São Paulo: Atheneu.

Freitas, L. W., Paz, I. C. L. A., Garcia, R. G., Caldara, F. R., Seno, L. O., Felix, G. A., Lima, N. D. S., Ferreira, V. M. O. S., \& Cavichiolo, F. (2011). Aspectos qualitativos de ovos comerciais submetidos a diferentes condições de armazenamento. Revista Agraria, 4(11), 66-72.

Garcia, E. R. M., Orlandi, C. C. B., Oliveira, C. A. L., Cruz, F. K., Santos, T. M. B., \& Otutumi, L. K. (2010). Qualidade de ovos de poedeiras semipesadas armazenados em diferentes temperaturas e períodos de estocagem. Revista Brasileira de Saúde e Produção Animal, 11(2), 505-518. 
Giampietro-Ganeco, A., Scatolini-Silva, A. M., Borba, H., Boiago, M. M., Lima, T. M. A., \& Souza, P. A. (2012). Estudo comparativo das características qualitativas de ovos armazenados em refrigeradores domésticos. Ars veterinary, 28(2), 100-104.

Hermiz, H. N., Abas, K. A., Al-Khatib, T. R., Amin, S. M., Ahmed, A. M., Hamad, D. A., \& Denha, H. P. (2012). Effect of strain and storage period on egg quality characteristics of the local Iraqi laying hens. Research Opinions in Animal \& Veterinary Sciences, 2(1), 98-101.

International Commission on Microbiological Specifications for Foods - ICMSF. (1980). Microbial Ecology de los Alimentos 2. Zaragoza: Editorial Acribia.

Keener, K. M., McAvoy, K. C., Foegeding, J. B., Curtis, P. A., Anderson, K. E., \& Osborne, J. A. (2006). Effect of Testing Temperature on Internal Egg Quality Measurements. Poultry Science Association. http://dx.doi.org/10.1093/ps/85.3.550

Laganá, C., Pizzolante, C. C., Turkish, P. H. N., Moraes, J. E., \& Saldanha, E. S. P. B. (2012). Influence of the natural dyes bixin and curcumin in the shelf life of eggs from laying hens in the second production cycle. Acta Scientiarum Animal Sciences, 34(2)155-159. http:// dx.doi.org/10.4025/actascianimsci.v34i2.12096

Leandro, N. S. M., Deus, H. A. S. B., Stringhini, J. H., Café, J. M. B., Andrade, M. A., \& Carvalho, F. B. (2005). Aspectos de qualidade interna e externa de ovos comercializados em diferentes estabelecimentos na região de Goiânia. Ciência Animal Brasileira, 6(2), 71-78.
Naves, M. M. V., Prado, C. M. M., Fernandes, D. C., \& Serafini, A. B. (2007). Avaliação microbiológica do pó da casca de ovo e otimização da técnica de elaboração do produto. Pesquisa Agropecuária Tropical, $37(2), 113-118$.

Oliveira, D. D., \& Silva, E. N. (2000). Salmonella spp em ovos comerciais: ocorrência, condições de armazenamento e desinfecção da casca. Arquivo Brasileiro de Medicina Veterinária Zootecnia, 52(6). http:// dx.doi.org/10.1590/S0102-09352000000600017

Rego, I. O. P., Cançado, S. V., Figueiredo, I. T. C., Menezes, L. D. M., Oliveira, D. D., Lima, A. L., Boiler, L. G. M., \& Esser, L. R. (2012). Influência do período de armazenamento na qualidade do ovo integral pasteurizado refrigerado. Arquivo Brasileiro de Medicina Veterinária Zootecnia, 64(3), 735-742. http://dx.doi.org/10.1590/ S0102-09352012000300027

Rodrigues, K. R. M., \& Salay, E. (2001). Atitudes de granjeiros, atacadistas, varejistas e consumidores em relação á qualidade sanitária do ovo de galinha in natura. Revista de Nutrição, 14(3), 185-193. http://dx.doi.org/10.1590/S1415-52732001000300004

Silva, N., Junqueira, V. C. A., \& Silveira, N. F. A. (1997). Manual de métodos de análise microbiológica de alimentos. São Paulo: Varela.

Souza-Soares, L. A., \& Siewerdt, F. (2005). Aves. Pelotas: Ed Universitária.

Taham, T., \& Oliveira, V. L. (2011). Pesquisa de Salmonella spp. em ovos comercializados na região do Distrito Federal. Cadernos de pós-graduação da FAZU, 2. 